\title{
Netstøttet undervisning på Copenhagen Business School
}

- implementering og brug af SiteScape Forum

\author{
Michael Pedersen \\ Konsulent \\ CBS Learning Lab \\ Copenhagen Business School \\ mp.11@cbs.dk \\ http://www.11.cbs.dk/
}

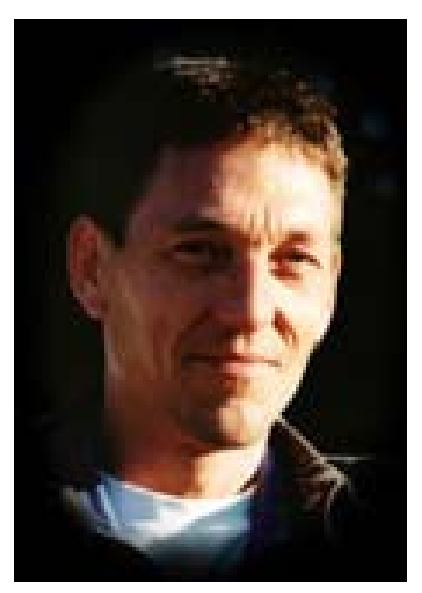

Michael Pedersen er ansat ved CBS Learning Lab (CBS LL) som konsulent med arbejdsområdet: Netstøttet undervisning. Fokus er på implementeringen og brug af platformen SiteScape Forum til netstøttet undervisning på CBS. Står for instruktion i brug af SiteScape for undervisere, administrative medarbejdere samt studerende på CBS, udvikling af brugerfunktionaliteter i SiteScape, evaluering af uddannelsernes brug af SiteScape og analyse andre platforme. Desuden udvikling af padagogiske kurser for undervisere inden for netstøttet undervisning.

\section{Lisette Rasmussen}

SiteScape-koordinator

Det Erhvervsøkonomiske Fakultet

Copenhagen Business School

1r.om@cbs.dk

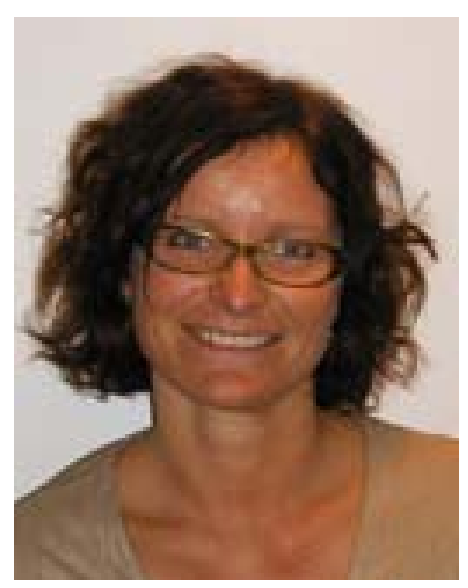

Lisette Rasmussen er af Det Erhvervsøkonomiske Fakultet som central koordinator af de administrative funktioner på CBS's undervisningsplatform, SiteScape. Dette indebcerer bl.a.: Hjoelp til det administrative og det videnskabelige personale, når et nyt studie ønsker at bruge SiteScape, administrativ tovholder på de store studier som HD 1. del, Cand.merc. og HA, oplaeg om og undervisning $i$ brugen af SiteScape, udarbejdelse af vejledninger, daglig support til brugerne samt evaluering af den administrative side af SiteScape. 


\section{Kort historik.}

CBS’s Erhvervsøkonomiske Fakultetsråd vedtog i 1998 et sæt pædagogiske mål-sætninger, som skal tjene som pejlemærke for studiernes stadige udvikling. I disse pædagogiske principper fremhæves bl.a.:

At "studierne bygger på, at konfrontationstimerne skal accelerere de studerendes læreproces, men at den vasentligste del af læreprocessen foregår uden for konfrontationstimerne."

Samt at "der anvendes en blanding af varierede, aktiverende undervisningsformer under hensyntagen til studietrin og fagdidaktiske forskelle. Der lægges specielt vægt på dialog, case-undervisning og projektarbejde."

Det fastslås, at "IT inddrages overalt, hvor det kan fremme indlæringen og effektiviteten i øvrigt."

(Se: http://www.cbs.dk/aboutcbs/dpu/pprincipper/pprincipper.shtml)

CBS Learning Lab har evalueret flere platforme (se f.eks. www.ll.cbs.dk/pdf_filer/platform.pdf), som kan bruges til netstøttet undervisning. Med udgangspunkt i de pædagogiske principper for Det Erhvervsøkonomiske Fakultet anbefalede CBS LL i 2000 at anskaffe SiteScape Forum som CBS's fælles platform for uddannelsernes integrering af netstøtte i undervisningen.

Platformen er et konferencesystem, hvor de enkelte uddannelser kan opbygge de workspaces, diskussionsfora og kalendere, som det er relevant at arbejde med. Det er i SiteScape muligt at arbejde med både asynkron og synkron dialog.

Kort opsummeret er SiteScape Forum valgt fordi:

- Platformen understøtter de pædagogiske principper, som er vedtaget af CBS

- Opbygning, struktur og komponenter i SiteScape kan tilpasses det enkelte studie

- Der er mulighed for integration af eksisterende oplysninger om studerende, dvs. samkøring med LDAP-serveren

- SiteScape Forum fungerer inden for de studerendes og CBS's tekniske rammer

- SiteScape Forum kræver ikke specialsoftware, kun en internetopkobling

- Supporten er enkel

I efteråret 2000 blev platformen testet på en uddannelse, HD Organisation. Siden er der sket en successiv udrulning på alle uddannelser efter frivillighedsprincippet. Pr. sommer 2003 har $95 \%$ af alle studerende og undervisere adgang til en studiezone i SiteScape Forum. Listen kan ses på http://www.e-cbs.dk

Pt. anvendes version 6 af Sitescape Forum. Version 7 testes i øjeblikket, og der er planer om at gå over til denne version i løbet af forårssemesteret 2004.

\section{Den administrative/organisatoriske synsvinkel på SiteScape Forum}

\section{Opbygningen af et studies SiteScape-zone}

Der er udviklet en fast procedure for et studies inddragelse af SiteScape Forum. 
Efter henvendelse fra et studie til den centrale koordinator eller CBS LL præsenteres SiteScape Forum for den fagligt ansvarlige og administratoren, og der diskuteres forskellige problemstillinger:

- Hvem skal administrere SiteScape Forum? - det er et krav, at der er en administrator lokalt på studiet.

- Hvordan er uddannelsens struktur/"flow"? Hvilke diskussions-fora er der behov for at opbygge?

- Hvad er den pædagogiske målsætning for uddannelsens brug af SiteScape Forum?

- Hvem skal undervises i SiteScape (administration, undervisere, studerende)?

CBS LL tager sig af de pædagogiske aspekter og problemstillinger, mens den centrale koordinator i fællesskab med administratoren og den fagligt ansvarlige udarbejder en plan for zonens opbygning. Herefter opretter den administrativt ansvarlige under supervision af den centrale koordinator studiets Sitescape-zone. Det vil som oftest være fagets/liniens/studiets administrator, som er lokal SiteScape-administrator, og processen med at opbygge strukturen fungerer samtidig som oplæring af lokaladministratoren. Efterfølgende kan den lokale administrator trække på såvel den centrale koordinator, CBS LL samt SiteScapes systemadministrator på CBS, hvis der opstår problemer eller tvivlsspørgsmål. Der er ydermere lavet en udførlig administratorvejledning, som lokaladministratorerne kan bruge i deres daglige arbejde.

SiteScape Forum er så at sige en tom skal uden struktur. Det enkelte studie vælger en opbygning med workspaces, diskussionsfora og kalendere, som afspejler studiets struktur, ønsker og behov. Udgangspunkter er ofte i studiets hjemmeside. Det betyder at fora som undervisningsnoter, informationer fra administrationen om undervisning og eksamen og daglige meddelelser er gengangere på de fleste studier. Altså fora af distributiv karakter.

Derudover forsøger flere og flere studier sig med fora, hvor de studerende selv kan lægge deres præsentationer op, hvor der kan afleveres opgaver, stilles spørgsmål og udveksles viden.

Alle registrerede brugere har som udgangspunkt rettigheder til at oprette deres egne teams indenfor studiets zone, hvilket bruges flittigt af studie- og projektgrupper. Fora af kommunikativ karakter bliver således mere og mere udbredte, efterhånden som studierne sætter sig det mål, at SiteScape ikke bare skal være en hjemmeside med begrænset adgang, men at de studerende og underviserne skal benytte platformen til aktiv kommunikation. Et enkelt studie har nu skåret ned på fremmødeundervisning til fordel for kontakt via SiteScape. 


\begin{tabular}{|c|c|}
\hline \multicolumn{2}{|l|}{$\begin{array}{l}\text { CBS Homepage } \\
\text { Zone Select Page } \\
\text { 1st_year }\end{array}$} \\
\hline \multirow{2}{*}{\multicolumn{2}{|c|}{$\begin{array}{l}\text { Workspace My summary Discussions } \checkmark \text { Messaging } \\
\text { User profile | List users | Administer | Wizards | List unseen | Send mail }\end{array}$}} \\
\hline & \\
\hline \multirow[t]{2}{*}{ 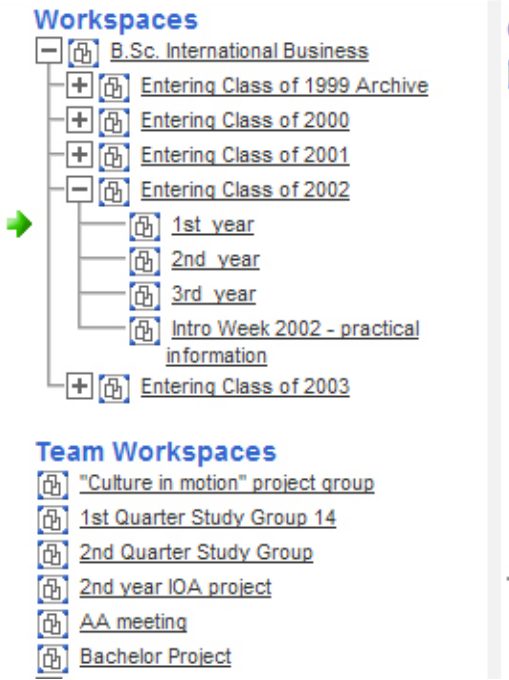 } & 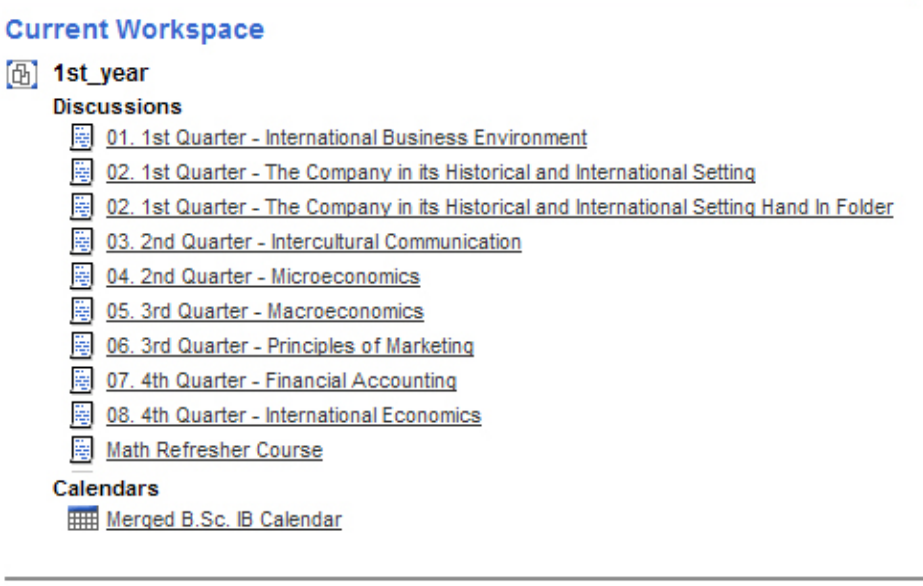 \\
\hline & $\begin{array}{l}\text { [區. Personal Space } \\
\text { 聖 My News }\end{array}$ \\
\hline
\end{tabular}

Figur 1. Eksempel på et studies opbygning (B.Sc. International Business)

NB! Studiet er set med administratorrettigheder. Den enkelte bruger ser kun de workspaces, diskussionsfora, kalendere og teams som vedkommende har adgang til.

\section{Uddannelse af brugerne.}

Når en uddannelse tager SiteScape i brug tilbydes underviserne ved uddannelsen enten et særligt tilrettelagt kursus, eller de kan deltage i et af de bredt udbudte introduktionskurser på CBS LL. Kurset er en blanding af hands-on og pædagogiske diskussioner samt en beskrivelse af aktuelle og fremtidige muligheder. Varigheden er på 7 timer, hvoraf hands-on delen udgør ca. 3 timer.

Studierne vælger selv, om de studerende skal tilbydes enten et instruerende oplæg eller et kort hands-on kursus i, hvordan man navigerer rundt i zonen, og hvordan man gør de mest elementære ting. Desuden tilbydes et opfølgende møde med de studerende for at afklare spørgsmål.

Ud over det generelle introduktionskursus har CBS LL kurser i planlægning af netstøttet undervisning. Fokus er her de pædagogiske aspekter ved at inddrage netstøtte og kurset gennemføres som netstøttet forløb. Underviserne kan deltage omkostningsfrit. Derudover kan studie- og fagledere søge konsulentbistand i forbindelse med ønsker om fagudvikling, hvori nettet (Sitescape Forum) ønskes inddraget.

\section{Den funktionelle synsvinkel på SiteScape Forum.}

Alle studerende på et studie oprettes automatisk med login/password som til deres mailkonto på CBS i studies Sitescape-zone. De indlæses som enkeltbrugere samt som medlem af en rettighedsgruppe (årgang, hold, fag). Der sker en daglig synkronisering med oplysninger fra studenterdatabasen, således at f.eks. nye studerende automatisk lægges ind i studiets SiteScape-zone, og studerende fra Åben Uddannelse, der ikke har betalt deres semesterafgift, fjernes fra rettighedsgruppen. 
Undervisere skal indlæses manuelt af lokaladministratoren, da der ikke foreligger oplysninger i underviserdatabasen, om hvilke studier og fag den enkelte underviser er tilknyttet. Login og password er også her som til deres CBS-mailkonto.

Alle brugere er som udgangspunkt registrerede brugere med nogle basale rettigheder, f.eks. adgang til zonen. De er derudover medlem af nogle rettighedsgrupper, f.eks. en studieårgang eller en lærergruppe. Men først når den enkelte brugers rettighedsgruppe tildeles rettigheder i workspaces, diskussionsfora og teams, vil vedkommende kunne arbejde i sin uddannelseszone. Disse rettighedsniveauer spænder fra 'ikke adgang' over 'læserettigheder', 'læse+skrive rettigheder', 'læse+skrive+ændre/slette egne indlæg', 'læse+skrive+ændre/slette egne og andres indlæg', 'ændre rettigheder' til 'fuld administration'.

Er rettighederne sat korrekt af lokaladministratoren, vil brugeren kun se de fora, der er relevante for vedkommendes studieordning, semester og fag.

Ud over de indlæste rettighedsgrupper kan nye opbygges frit af lokaladministratoren eller, hvad angår teams, af brugeren selv. Alle brugere har oftest rettighed til at oprette egne teams til gruppeog projektarbejde med diskussionsfora og kalender, og her har de fulde administrative rettigheder. Brugerne er således ikke fastlåste i en defineret rettighedsgruppe, men kan som enkeltbruger eller gruppe tildeles forskellige rettigheder, afhængigt af hvor på studiets zone de skal arbejde.

En generel flash-introduktion til mulighederne på SiteScape Forum kan ses på: http://www.1l.cbs.dk/sitescape/intro1.html

En yderligere beskrivelse af funktioner i SiteScape Forum findes i brugervejledningen: http://www.1l.cbs.dk/pdf filer/SSFvejledning_User6.pdf

Studiernes brug af SiteScape Forum

På bacheloruddannelserne bruger flertallet af studierne primært SiteScape Forum til distribution af undervisningsmaterialer, underviser- og studenterpræsentationer og information fra studieadministrationen. Det hænger bl.a. sammen med, at det fra CBS's side prioriteres, at de studerende mødes på campus og danner sociale og uddannelsesnetværk. Behovet for netbaseret dialog er derfor ikke så markant.

Det er mere udbredt at anvende platformen til dialog på HD- og Masterstudierne, hvilket bl.a. skyldes, at der er tale om deltidsstuderende, som efterspørger fleksible tilbud. De har som regel fuldtidsjobs ved siden af studiet, har ofte familie og nogle bor endda i udlandet, hvorfor disse studerende i højere grad kan profitere af muligheden for at kunne kommunikere såvel synkront som asynkront på alle tider af døgnet. Derfor har det også været nemmere for underviserne at indtænke nye netbaserede pædagogiske muligheder for dialog om faglige spørgsmål på disse studier. Muligheden for at oprette teams til egne formål bliver dog benyttet på alle studier. Primært anvendes teams til studiegrupper og projektopgaver.

\section{Forskningsprojekter på SiteScape Forum}

Som noget nyt har forskningsprojekter, hvor CBS's medarbejdere er involveret, fået deres egne zone på SiteScape. Anonyme brugere, dvs. alle der prøver at logge på, har adgang til listen over forskningsprojekter samt til projekternes informationsfora, hvor man kan finde kontaktoplysninger, projektbeskrivelser, links til publikationer osv. Derudover kan kun de enkelte projekters medarbejdere komme ind på deres egne projekter. På den måde kan der samarbejdes og deles viden på tværs af kontorer, institutter og uddannelsesinstitutioner på en platform, hvor materialet kan bevares for- 
troligt, indtil det er bearbejdet og klar til offentliggørelse. Zonen kan findes på www.e-cbs.dk under Andre links og Research Projects at CBS.

\section{Tilfredshed med SiteScape}

Der hersker en generel tilfredshed med SiteScape Forum som undervisningsplatform. Det skyldes for en dels vedkommende, at platformen har sin lokale forankring hos en administrator, som kender studiets form og struktur. Studierne kan opbygge platformen som den svarer til de ønsker man har på studiet. Platformen dækker de fleste af de behov, der pt. er for netstøttet undervisning, og den er nem at arbejde med for såvel undervisere som studerende. Administrationssiden er rimeligt overskuelig, og det har lettet lokaladministratorerne meget, at der er kommet en administratorvejledning samt en central koordinator. Lokaladministratorerne er nu også så rutinerede, at de i vid udstrækning selv kan yde support til undervisere og studerende. Den daglige administration og brug af platformen kører således forholdsvist gnidningsfrit.

Der kan opstå frustrationerne - specielt fra de betalende studerendes side - når der opstår tekniske problemer f.eks. i forbindelse med synkroniseringen med de øvrige databaser. Hvis en studerende ikke har meldt eller ikke er registreret med studie-, linie- eller fagskift officielt vil denne studerende ikke overføres til de rette fora og har dermed ikke adgang til relevant studiemateriale.

\section{CBS's fremtidige valg af platform.}

SiteScape Forum har været i brug siden 2000. I denne periode er der høstet en del erfaringer, og på de meget aktive studier efterspørges nu nye funktioner til undervisning og administration, som ikke findes i SiteScape Forum version 6.

Flere studier har f.eks. omlagt opgaveudlevering og -aflevering til SiteScape Forum. Platformen giver mulighed for, at den enkelte bruger kan aflevere sin opgave, uden at andre end en såkaldt 'moderator' - f.eks. underviseren eller administratoren - har adgang til den. Men platformen mangler en mulighed for at kunne frigive opgaver på et givent forudbestemt tidspunkt og efterfølgende lukke for aflevering, når en tidsfrist er udløbet.

Derudover har andre studier udtrykt ønske om bedre synkrone online værktøjer (f.eks.videomøder med whiteboard). Dette rummer SiteScape Forum ikke i den nuværende version 6. Version 7 indeholder denne mulighed som et tilkøbsværktøj.

På nogle uddannelser er det endvidere et ønske, at der er bedre værktøjer for underviserne til strukturerede tilrettelagte undervisningsforløb. At man ved hjælp af templates kan lægge øvelser, øvelsesrækkefølger og tests op. Dette er ikke indeholdt i SiteScape Forum, bl.a. fordi platformen i sin oprindelse ikke er beregnet til instruktionsbrug, men til en virksomheds organisering af den interne og eksterne kommunikation.

På studier, hvor en stor del af undervisningsaktiviteterne er omlagt til platformen, savnes også en mulighed for at få en systematisk oversigt over egne og andre brugeres aktiviteter.

Blandt andet på baggrund af ovenstående ønsker er CBS Learning Lab i gang med at etablere et analyseprojekt. Indholdet i projektet er at evaluere den tekniske, administrative og pædagogiske brug af SiteScape Forum på CBS og efterfølgende specificere, hvilke krav - i prioriteret rækkefølge - CBS skal stille til en kommende undervisningsplatform. Evalueringen vil tage sit udgangspunkt $i$ interviews og fokusgrupper med undervisere, studerende og lokaladministratorer. Deltagerne vil blive bedt om at fortælle om deres erfaringer med SiteScape og gøre rede for såvel fordele som mangler ved og ønsker til platformen. Om SiteScape Forum også vil blive valget efter denne evaluering er uvist. Grundlæggende er der udbredt tilfredshed med platformen og et eventuelt platform- 
Tidsskrift for Universiteternes efter- og videreuddannelse (ISSN 1603-5518). 1. årgang, nr. 2, 2004

skifte skal derfor begrundes i, at en ny platform mindst skal have de samme faciliteter som SiteScape Forum. 